Endokrynologia Polska

DOI: 10.5603/EP.a2017.0040

Tom/Volume 68; Numer/Number 5/2017

ISSN 0423-104X

\title{
Clinical and immunological changes in patients with active moderate-to-severe Graves' orbitopathy treated with very low-dose rituximab
}

\author{
Zmiany kliniczne i immunologiczne u chorych z czynną, umiarkowaną lub \\ ciężką orbitopatią tarczycową leczonych bardzo małymi dawkami rytuksymabu
}

\author{
David Karasek', Lubica Cibickova', Marta Karhanova'2, Jana Kalitova², Jan Schovanek¹, Zdenek Frysak ${ }^{1}$ \\ ${ }^{1} 3^{\text {rd }}$ Department of Internal Medicine - Nephrology, Rheumatology and Endocrinology, Faculty of Medicine and Dentistry, Palacky \\ University, University Hospital, Olomouc, Czech Republic \\ ${ }^{2}$ Department of Ophthalmology, Faculty of Medicine and Dentistry, Palacky University, University Hospital, Olomouc, Czech \\ Republic
}

\begin{abstract}
Introduction: Glucocorticoids represent the therapy of choice for active and moderate-to-severe Graves' orbitopathy (GO). In some patients, rituximab, a monoclonal antibody against the cluster of differentiation (CD) 20 receptor of B-lymphocytes, can serve as a second-line or an alternative treatment. The effect of very low-dose of rituximab on the clinical activity of GO and corresponding clinical or laboratory changes is reported.

Material and methods: Changes of Clinical Activity Score (CAS) for GO, proptosis, levels of thyroid-stimulating hormone receptor antibodies, and depletion of CD19+ and CD20+ B-lymphocytes were determined in ten patients (two men and eight women) with active moderate-to-severe GO treated with a single 100-mg dose of rituximab. Correlations between differences of clinical and laboratory parameters were performed.

Results: A significant decrease of CAS was found during subsequent examinations compared to the baseline values. A significant depletion of CD19+ and CD20 + B-lymphocytes was detected after rituximab administration. Differences between follow-up and baseline levels of CD20+ positively correlated with differences in CAS after six $(p<0.05)$ and 12 months $(p<0.01)$. Differences in CD19+ levels correlated with differences in CAS after 12 months $(p<0.05)$ of the treatment. Two patients developed dysthyroid optic neuropathy (DON) requiring orbital decompression. No other rituximab side effects were reported during the whole study duration.

Conclusions: A single very low-dose of rituximab appears to be very well tolerated and effective enough to reduce clinical activity in active moderate-to-severe GO patients without impending DON. (Endokrynol Pol 2017; 68 (5): 498-504)
\end{abstract}

Key words: Graves' orbitopathy, rituximab, clinical activity score, thyroid gland, dysthyroid optic neuropathy

\section{Streszczenie}

Wstęp: Glikokortykoidy są leczeniem z wyboru w czynnej, umiarkowanej lub ciężkiej orbitopatii tarczycowej (Graves' orbitopathy, GO). U niektórych pacjentów jako leczenie drugiej linii lub leczenie alternatywne można zastosować rytuksymab, przeciwciało monoklonalne przeciw receptorowi kompleksu różnicowania (cluster of differentiation, CD) 20. W niniejszej pracy opisano wpływ bardzo małych dawek rytuksymabu na aktywność kliniczną GO i odpowiednie zmiany parametrów klinicznych i laboratoryjnych.

Materiał i metody: U 10 chorych (2 mężczyzn i 8 kobiet) z czynną, umiarkowaną lub ciężką GO, którym podano pojedynczą dawkę $100 \mathrm{mg}$ rytuksymabu, oceniono zmiany oceny w skali aktywności klinicznej (Clinical Activity Score, CAS) orbitopatii tarczycowej, stopnia wytrzeszczu, stężenia przeciwciał przeciw receptorom hormonu tyreotropowego (thyroid-stimulating hormone, TSH) oraz liczby limfocytów B typu CD19+ i CD20+. Zbadano korelacje między zmianami parametrów klinicznych i laboratoryjnych.

Wyniki: W kolejnych badaniach stwierdzono zmniejszenie aktywności choroby ocenianej w skali CAS w porównaniu z wartościami wyjściowymi. Po podaniu rytuksymabu zaobserwowano zmniejszenie liczby limfocytów B typu CD19+ i CD20+. Różnice między liczbą limfocytów CD20+ podczas kolejnych wizyt kontrolnych a wartością wyjściową korelowały dodatnio z różnicami wartości wskaźnika CAS po $6(\mathrm{p}<0,05)$ i 12 miesiącach $(\mathrm{p}<0,01)$. Różnice w liczbie limfocytów CD19+ korelowały z różnicami wartości wskaźnika CAS po 12 miesiącach $(p<0,05)$. U 2 chorych rozwinęła się neuropatia nerwu wzrokowego w przebiegu orbitopatii tarczycowej (dysthyroid optic neuropathy, DON) wymagająca dekompresji oczodołu. Nie stwierdzono innych działań niepożądanych rytuksymabu w trakcie badania. Wnioski: Pojedyncza bardzo mała dawka rytuksymabu była bardzo dobrze tolerowana przez chorych i wystarczająco skuteczna w zmniejszaniu aktywności klinicznej choroby u pacjentów z czynną, umiarkowaną lub ciężką GO bez zagrażającej DON. (Endokrynol Pol 2017; 68 (5): 498-504)

Słowa kluczowe: orbitopatia tarczycowa, rytuksymab, skala aktywności klinicznej, tarczyca, neuropatia nerwu wzrokowego w przebiegi orbitopatii tarczycowej 


\section{Introduction}

Graves' orbitopathy (GO) is an autoimmune disorder of the orbital tissues that develops in $25-50 \%$ patients with Graves' disease [1,2]. It may also occur in patients without any current or prior hyperthyroidism (euthyroid or ophthalmic Graves' disease) or in hypothyroid patients due to chronic autoimmune thyroiditis [3]. GO is an inflammatory process characterised by oedema and inflammation of the extraocular muscles and an increase in orbital connective tissue and fat resulting in periorbital and conjunctival oedema, chemosis, lid retraction, exophthalmos, and dysmotility of eye muscles, accompanied by spontaneous retrobulbar pain, pain on eye movement, watery and burning eyes, and/or diplopia [1, 2, 4]. Severe GO leads to exposure keratopathy and compressive optic neuropathy (dysthyroid optic neuropathy - DON), which may cause visual loss $[1,4,5]$.

Although during recent years researchers have provided interesting data on the aetiology and pathogenesis leading to development of GO, the exact pathological mechanism still remains unclear. Some risk factors were identified. Modifiable factors include smoking, thyroid dysfunction, radioiodine treatment for hyperthyroidism, and high thyroid-stimulating hormone (TSH) receptor antibody levels. Genetics, age, and gender are non-modifiable factors $[1,2,6]$. Shared thyroid and orbital antigens play an important role in the development of autoimmune process. Autoimmunity is probably triggered by recognition of the TSH receptor (TSH-R) expressed by fibroblasts and adipocytes after their differentiation from preadipocytes $[1,2,6]$. Type I insulin-like growth factor receptor, another antigen presented by orbital fibroblasts, and $\mathrm{T}$ and B lymphocytes, may also be involved in the initiation or maintenance of orbital autoimmunity $[1,2,6]$. After recognition of autoantigens, a number of reactions occur leading to proliferation of orbital fibroblasts, differentiation of preadipocytes into adipocytes, production of autoantibodies, secretion of cytokines, infiltration of extraocular muscles, and increased secretion of glycosaminoglycans [2].

High-dose systemic glucocorticoids are currently the first-line treatment for active and moderate-to-severe GO [7]. More recent studies suggest that pulsed intravenous methylprednisolone is more effective and has an improved side-effect profile compared to high-dose oral prednisone $[7,8]$. This therapy is effective in $70-80 \%$ of patients, compared to $50 \%$ in those treated orally $[2,4,7]$. However, a significant proportion of them (20-30\%) do not respond to glucocorticoids, and furthermore approximately $10-20 \%$ of all treated patients relapse after therapy withdrawal [8]. For these reasons, novel immunosuppressive agents targeting other pathogenic mechanisms have been introduced for GO treatment. Among them, rituximab has received particular attention in the last few years. Rituximab is a monoclonal antibody targeting the cluster of differentiation (CD) 20 transmembrane antigen expressed by pre-B and mature B lymphocytes, but not by stem cells or plasma cells [9]. Its main effect is to deplete CD20-positive B-cells. Because plasma cells are not affected, antibody production is usually maintained. Immunosuppressive action of rituximab is probably mediated by the reduced activity of B cells as antigen-presenting cells and the decreased production of inflammatory cytokines. A potential indirect blockade of pathogenic autoantibody generation is also suggested [8,9]. Standard rituximab GO treatment regimen is usually $1000 \mathrm{mg}$ intravenously twice at two-week intervals. However, a single $500 \mathrm{mg}$ dose had a similar effect on GO clinical activity [10]. Moreover, Salvi M et al. demonstrated the effect of $100 \mathrm{mg}$ rituximab on peripheral B-cell depletion and subsequent induction of GO long-term remission in two patients who did not receive a full dose due to an infusion reaction (progression of orbital soft tissue swelling) [11].

The aim of this paper is to report clinical and immunological changes in patients with active moderateto-severe GO, who were treated with very low-dose rituximab.

\section{Material and methods}

The group consisted of ten Caucasian individuals (two men and eight women; three smokers and seven non-smokers; age range 27-74 years, average age $49.3 \pm$ 13.4 years), affected with active GO (GO duration 8.9 \pm 5.7 months), defined by a clinical activity score (CAS $=$ number of positive signs: spontaneous retrobulbar pain; pain on attempted up or down gaze; redness of the eyelids; redness of the conjunctiva; swelling of the eyelids; inflammation of the caruncle and/or plica; conjunctival oedema) $\geq 3[3,12]$, and of moderate-to-severe degree, as defined by EUGOGO severity assessment (patients without sight-threatening GO and with two or more of the following: lid retraction $\geq 2 \mathrm{~mm}$, moderate or severe soft-tissue involvement, or exophthalmos $\geq 3 \mathrm{~mm}$ above normal for race and gender, no or intermittent diplopia and corneal exposure responsive to lubricants) [3]. Six patients were after total thyroidectomy, and three were after radioiodine therapy. Thyroid function tests were normal in all of them. Patients signed informed consent forms approved by the institutional Ethics Committee of the Medical Faculty and University Hospital Olomouc. They were treated by rituximab in the period from 


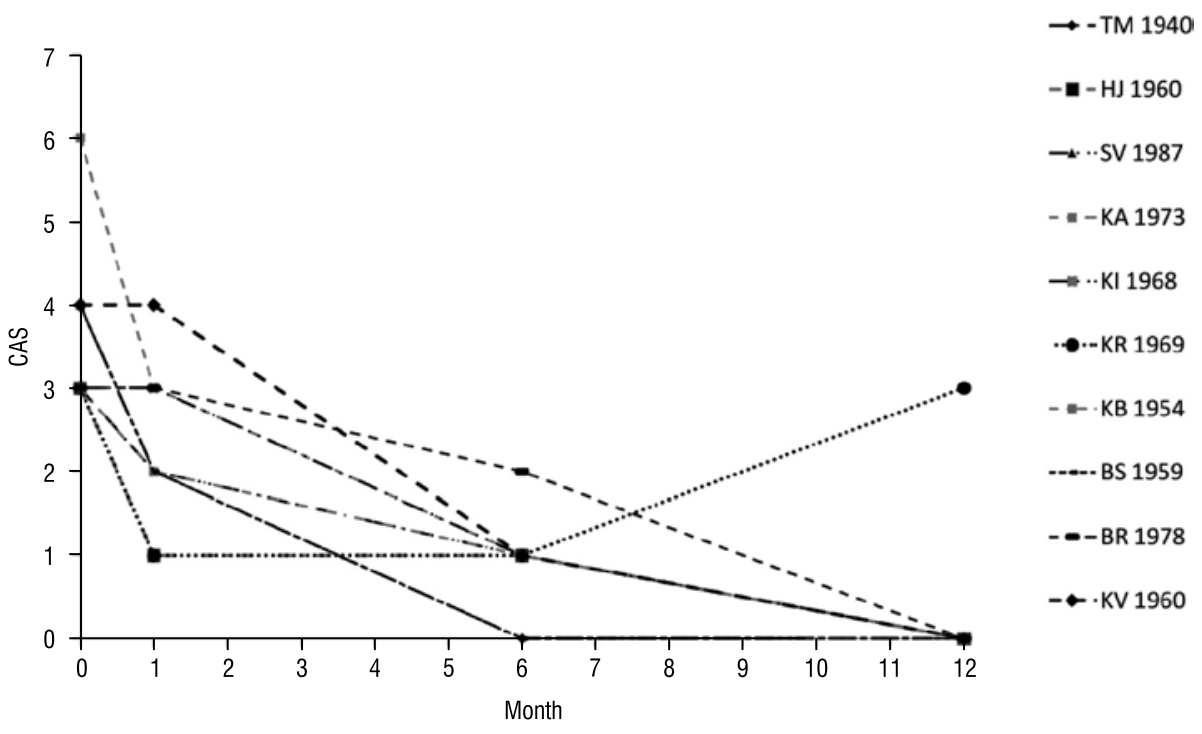

Figure 1. Changes in clinical activity score (CAS) in individual patients

Rycina 1. Zmiany skali aktywności klinicznej (CAS) u pacjenta

July 2013 to April 2015, and all of them were regularly checked for at least a year.

Indications for rituximab administration were: persistently high GO activity $(\mathrm{n}=4)$ or its reactivation $(n=3)$ after previous treatment by pulsed intravenous methylprednisolone (average previous cumulative dose of methylprednisolone was $7.3 \pm 1.9 \mathrm{~g}$ ) or contraindications for this therapy $(\mathrm{n}=3)$. Intravenous application of $100 \mathrm{mg}$ rituximab dose lasted for two hours. Infusion reaction to rituximab application was prevented by administration of methylprednisolone (100 mg), paracetamol (500 mg), and bisulepine (2 mg) before and by administration of paracetamol $(500 \mathrm{mg})$ and bisulepine ( $2 \mathrm{mg}$ ) after the infusion.

Complete ophthalmological assessment (including visual acuity, evaluation of adnexa and eyelids, slit-lamp evaluation of anterior segment, fundus evaluation by indirect ophthalmoscopy, Hertel measurement, and ultrasound measurement of extraocular muscle thickness) was made before rituximab administration and after one, six, and 12 months, respectively. The effect of therapy was monitored by assessment of CAS and by exophthalmos examination. Grade of proptosis was measured by Hertel exophthalmometer (taken from the lateral orbital rim to the corneal apex in millimetres for each eye and then average value calculated from both eyes).

The effect of rituximab on lymphocyte subpopulations was analysed with a standard antibody panel for CD20+ and CD19+ subpopulations at baseline and after one month. TSH-R antibodies (TRAbs) were measured as TSH-R binding inhibitory immunoglobulins using a third-generation assay at baseline and after six and 12 months. Differences between baseline and follow-up levels of laboratory markers were calculated and correlated with differences in CAS and average proptosis.

Statistical analyses were performed using SPSS for Windows version 12.0 (Chicago, IL, USA). Parameters with normal distribution (normality was tested with Kolmogorov-Smirnov test) were expressed as mean \pm $\mathrm{SD}$, parameters with skewed distribution as median (first to third quartile of values). Differences in values of repeated measurements were analysed by Wilcoxon test. Spearman's rank correlation analysis tested univariate correlations between parameters. Probability values of $p<0.05$ were considered as statistically significant.

\section{Results}

CAS improved in most patients after one month, and the improvement continued (Fig. 1). One patient after initial regression of disease activity suffered from late partial GO reactivation (CAS increased to 3.0 a year after rituximab administration) probably due to smoking resumption. This patient was then successfully treated by a low-dose of oral prednisone, and during three months CAS decreased to 0 . In the further observation we did not register any disease reactivation in any treated patient until submission of this paper.

Two patients developed DON requiring orbital decompression (during the first and fourth month after rituximab therapy). Both were corticoid-resistant and were excluded from the subsequent statistical evaluation. Elective orbital decompression was also performed in one patient later (at $17^{\text {th }}$ month after therapy) during 
Table I. Clinical and laboratory parameters at baseline and after rituximab administration Tabela I. Parametry kliniczne i laboratoryjne na początku badania i po podaniu rytuksymabu

\begin{tabular}{lllll}
\hline & At baseline & At month one & At month six \\
after rituximab & after rituximab & $0.8 \pm 0.4^{* *}$ & $0.4 \pm 0.9^{* *}$ \\
\hline CAS & $3.6 \pm 0.9$ & $2.0 \pm 0.8^{* *}$ & $21.5 \pm 1.7$ & $21.1 \pm 1.8^{*}$ \\
\hline AP $(\mathrm{mm})$ & $22.3 \pm 1.6$ & $21.8 \pm 1.6$ & - & - \\
\hline CD19+ (\%) & $4.04 \pm 1.67$ & $0.22 \pm 0.20^{*}$ & - & - \\
\hline CD20+ (\%) & $4.23 \pm 1.59$ & $0.03 \pm 0.07^{*}$ & $1.6(1.0-6.9)^{*}$ \\
\hline TRAbs (IU/L) & $5.7(1.1-41.0)$ & - & $2.1(0.2-5.7)^{*}$ \\
\hline
\end{tabular}

CAS - clinical activity score, AP — average proptosis, CD19+ - proportion of lymphocyte with CD (cluster of differentiation) marker 19 , CD20+ - proportion of lymphocyte with CD marker 20, TRAbs - thyroid-stimulating hormone receptor antibodies

Values are expressed as mean \pm standard deviation, for parameters with skewed distribution (TRAbs) as median $\left(25^{\text {th }}\right.$ and $75^{\text {th }}$ percentiles)

$*^{*} \sim p<0.05,{ }^{*} \sim p<0.01$ statistical significance level (comparison with baseline values, Wilcoxon test)

Table II. Correlations between differences of clinical and laboratory parameters

Tabela II. Korelacje między różnicami w wartościach parametrów klinicznych i laboratoryjnych

\begin{tabular}{lllll}
\hline & $\Delta$ CD19+ & $\Delta$ CD20+ & $\Delta$ TRAbs 0-6 & $\Delta$ TRAbs 0-12 \\
\hline$\Delta$ CAS 0-1 & n.s. & n.s. & n.s. & n.s. \\
\hline$\Delta$ CAS 0-6 & $\rho=0.93, p<0.05$ & $\rho=0.88, p<0.05$ & n.s. & n.s. \\
\hline$\Delta$ CAS 0-12 & n.s. & $\rho=0.78, p<0.05$ & n.s. & n.s. \\
\hline$\Delta$ AP 0-1 & n.s. & n.s. & n.s. & n.s. \\
\hline$\Delta$ AP 0-6 & n.s. & n.s. & n.s. & n.s. \\
\hline$\Delta$ AP 0-12 & n.s. & n.s. & n.s. & n.s. \\
\hline$\Delta$ TRAbs 0-6 & n.s. & n.s. & $\rho=1$ & n.s. \\
\hline$\Delta$ TRAbs 0-12 & n.s. & n.s. & n.s. & $\rho=1$ \\
\hline
\end{tabular}

$\triangle \mathrm{CAS}$ - CAS at baseline - CAS after one (0-1), six (0-6), or 12 (0-12) months, $\triangle \mathrm{AP}$ - AP at baseline - AP after one (0-1), six (0-6), or 12 (0-12) months, $\triangle \mathrm{CD} 19+$ - CD19+ at baseline - CD19+ after one month, $\triangle \mathrm{CD} 20+-\mathrm{CD} 20+$ at baseline - CD20+ after one month, $\triangle$ TRAbs - TRAbs at baseline - TRAbs after six (0-6) or 12 (0-12) months of rituximab administration

CAS - clinical activity score, AP — average proptosis, CD19+ — proportion of lymphocyte with CD (cluster of differentiation) marker 19, CD20+ - proportion of lymphocyte with CD marker 20, TRAbs - thyroid-stimulating hormone receptor antibodies

$\rho$ (rho) - Spearman's correlation coefficient, $p$ - level of statistical signification, n.s. — not significant

inactive phase of GO for exophthalmos with intermittent spontaneous eyeball subluxation. We did not encounter any other clinical or laboratory side effects of $100 \mathrm{mg}$ rituximab treatment during the whole study duration.

Table I shows the clinical and laboratory parameters before and after administration of rituximab. There was a significant CAS decrease within one month and then within six and 12 months compared to the baseline values. A significant depletion was detected in CD19+ and CD20+ B-lymphocytes after rituximab administration. There was also a significant decrease of TRAbs within six and 12 months compared to baseline values. A mild proptosis decrease was observed up to 12 months after the treatment.

Further statistical evaluation of monitored parameters and their relationships is shown in Table II. Differences between follow-up and baseline levels of CD20+ cells $(\triangle \mathrm{CD} 20+)$ positively correlated with differences in CAS after six months ( $\triangle$ CAS $0-6, \mathrm{p}<0.05$ ) and after 12 months $(\triangle$ CAS $0-12, \mathrm{p}<0.01)$ following rituximab administration. Difference between follow-up and baseline levels of CD19+ cells $(\Delta \mathrm{CD} 19+)$ positively correlated with differences in CAS after 12 months (CAS 0-12, $\mathrm{p}<0.05)$ only. There were no other significant correlations.

\section{Discussion}

Administration of a very low-dose of rituximab resulted in a significant depletion of B-cells and a suppression of GO clinical activity. Treatment was long-term effective and safe.

The first case report on successful treatment of moderate-to-severe GO with rituximab was published in 2006 [13]. Since that time several mostly smaller, open, and non-controlled studies have been performed with promising findings $[7,14,15]$. However, two recent randomised controlled trials published in the last year revealed rather different results $[10,16]$. 
Salvi et al. confirmed a better therapeutic outcome of rituximab $(2 \times 1000 \mathrm{mg})$ in active moderate-to-severe $\mathrm{GO}$, when compared with intravenous methylprednisolone, even after a lower rituximab dose $(1 \times 500 \mathrm{mg})$ [10]. CAS decreased in both therapeutic modes but more after rituximab (100 vs. 69\% after intravenous methylprednisolone). Moreover, the patients treated with rituximab showed better eye motility outcome, visual functioning of the quality of life assessment, and a reduced number of surgical procedures compared to patients treated with glucocorticoids. GO reactivation never occurred after rituximab, although it did in $31 \%$ of patients after intravenous methylprednisolone [10].

By contrast, Stan et al. did not find any significant reduction in CAS assessed as a continuum and separately as improvement by $\geq 2$ points at 24 weeks after two rituximab infusions (1000 $\mathrm{mg}$ each) compared to placebo [16]. CAS at 24 and 52 weeks improved from baseline in most patients similarly in both groups. In addition, there were no differences in the secondary assessments that included multiple quantitative measures of disease severity, the NOSPECS classification [7], a composite assessment of treatment failure, and a quality of life questionnaire [16].

These discrepant results may be elucidated by the differences in study population, degree of GO activity, and disease duration [7,8]. Another explanation for the same CAS improvement in both groups (rituximab versus placebo) in the latter study could be the effect of the natural course of GO as a self-limiting autoimmune disease. However, several case report studies demonstrated the relationship between rituximab administration and a decrease of inflammatory orbital infiltration, particularly complete depletion of CD20+ lymphocytes [11, 14, 17]. Significant changes of ${ }^{99 \mathrm{~m}} \mathrm{Tc}-$ labelled diethylenetriaminepentaacetic acid orbital uptake and of T2 relaxation times of extraocular muscles on magnetic resonance imaging showing the effect of rituximab treatment for GO were also reported [18]. Positive correlations between CAS improvement and decrease of CD20+ and CD19+ lymphocytes and lack of a correlation between CAS improvement and TRAbs decrease in our study group favour the therapeutic effect of rituximab over the natural course of disease on GO clinical activity.

The question of the appropriate dose for therapy of active GO remains unanswered. Results of recent studies showed that rituximab may be effective in patients with GO even at lower doses than currently recommended in autoimmune rheumatic diseases [8]. Mitchell et al. used rituximab to treat eight patients with active, steroid-refractory GO and one with inactive disease. Although three patients received the full dose of $1000 \mathrm{mg}$ twice, six received only $500 \mathrm{mg}$ twice, and one of them $500 \mathrm{mg}$ three times, until a peripheral B-cell depletion was attained. Reduction of CAS was seen in all cases [19]. In the previously mentioned study Salvi et al. found CAS decrease in moderate-severe GO independent of the rituximab dose (1000 or $500 \mathrm{mg}$ ) [9]. Our findings focused on $100 \mathrm{mg}$ of rituximab as the sufficient dose to induce a significant B-lymphocyte depletion and a reduction of CAS. Similar results were also presented by Vannuchi et al. [20]; a single very low-dose of rituximab (100 mg) was effective in inactivating GO in $12 / 14$ patients $(85.7 \%)$ with short disease duration. As well as economic benefit, a lower dose of rituximab should be connected with lower frequency of dosedependent side effects. Infusion-related reactions are the most frequently reported short-term side effects of rituximab that may occur in about $10-30 \%$ of patients at its first infusion [7]. Rarely, transient but significant periorbital oedema and inflammation may also occur [11]. We did not register any of them.

Duration of action of rituximab treatment may be potentially affected by its dose. However, similar duration of CD20+ and CD19+ peripheral cell depletion was observed in two patients after receiving $100 \mathrm{mg}$ of rituximab, as in 10 patients treated with two cycles of $1000 \mathrm{mg}$ of rituximab for active GO [11]. Treatment response may, of course, be individual, but the mean reported duration of peripheral B-cell depletion in patients with GO treated by rituximab was $16.7 \pm 2.1$ weeks [21]. Salvi et al. did not observe any GO reactivation after higher dose of rituximab [10]. One of our patients suffered from a late partial reactivation a year after the treatment. We suppose that it was probably due to the patient's non-compliance (smoking resumption) and was not related to the rituximab dose. Still, it is not known if very low-dose of rituximab may modify the natural course of disease, as has been observed with higher therapeutic doses [8].

Two patients developed DON requiring orbital decompression (within one month and four months after rituximab). One of them exhibited initial signs of DON at the time of treatment. They both were glucocorticoid-resistant, and rituximab represented the second-line therapeutic option. Surgical decompression led to a complete recovery [22]. Rituximab was successfully used in patients with DON [19, 23, 24], but available evidence from one of the randomised studies [16], as well as a case report of a patient with glucocorticoid-resistant GO [25], suggests that progression of DON may occur after rituximab, even after its higher doses. Vannuchi et al. reported two patients not responding to a single very low-dose of rituximab (100 mg), who developed DON treated with a surgical orbital decompression [20]. Based on the above, recent ETA/EUGOGO guidelines do not recommend 
rituximab for patients with impending DON or long duration of disease [7].

Contrary to GO activity, the severity of GO evaluated by proptosis measurement changed much less during the treatment and did not correlate with peripheral B-cell depletion in our study group. Proptosis or NOSPECS improvement has been seen in some open studies and in several case reports [11, 13, 14,19]. However, results from randomised trials $[10,16]$ and other retrospective, interventional case series [23] did not show significant effect of rituximab (even in higher doses) on changes of these GO severity markers. Salvi et al. found better eye motility outcome and a reduced number of surgical procedures in patients treated with rituximab compared to patients treated with glucocorticoids [10]. However, Stan et al. documented no differences between treated and placebo groups in changes of proptosis, diplopia, lid fissure width, lagophthalmos, or NOPSPECS score improvement [16]. GO severity improvement is long lasting and there are other factors (genetic factors, ancestry, gender, thyroid function, local anatomical conditions, smoking, radioactive iodine therapy, etc.), which can modify this process [26].

We observed significant decrease of TRAbs during the treatment, but the changes of TRAbs did not correlate with changes of clinical activity or with B-cell depletion in our study. There is inconsistent evidence on the effect of rituximab on TRAbs circulating antibodies in other studies [15]. A significant decrease of TRAbs was observed during the treatment, but mostly not related to B-cell depletion [14, 19, 21, 27]. El Fassi et al. reported that rituximab may favourably affect Graves' disease remission by distinctively affecting production of the thyroid-stimulating autoantibodies (TSAbs) in a small group of patients [28]. We were not able to measure this subpopulation of TRAbs. However, Vannucchi et al. did not confirm previously suggested distinct effect of rituximab on serum TSAbs, also measured as immunoglobulinstimulation of cAMP by TSH-R transfected Chinese hamster ovary cells [21]. Most findings suggest that rituximab does not have an effect on either thyroid or orbital autoantibody production, while acting in a distinct way on the compartments of lymphocytic infiltrates of the thyroid and the orbit tissues [14, 21, 23]. Generally, its rapid therapeutic effect observed in autoimmune diseases argues against an antibody-mediated action [21]. Also, TRAbs levels decreased during a study comparing patients treated by rituximab or by placebo similarly in both patient groups [16]. So, the decrease of circulating TRAbs levels may reflect the natural course of the GO rather than the effect of rituximab treatment.
Our study has several limitations. This was an open, non-controlled, non-randomised study. The number of patients was small. There were $80 \%$ of women and only $20 \%$ of men. Heterogeneity of the treated group was given also by age variance, duration of $\mathrm{GO}$, and its previous treatment. There were seven glucocorticoidresistant patients. Three subjects were naive to glucocorticoid treatment. Due to low disease incidence, we can find similar limitations also in some previously published studies. Multicentre trials recruiting greater numbers of patients seems to be an adequate solution for this problem.

\section{Conclusions}

Although reported findings were not derived from a randomised, controlled, large trial, some important conclusions can still be drawn. A single very low-dose of rituximab appears to be very well tolerated and effective enough to reduce clinical activity in active and moderate-to-severe GO patients without impending DON. However, larger, randomised, controlled trials will be necessary to confirm these results and find the optimal dose of rituximab in various groups of GO patients.

Supported by MH CZ DRO (FNOl, 00098892) — 87-62.

\section{References}

1. Bahn RS. Graves' ophthalmopathy. N Engl J Med. 2010; 362(8): 726-738, doi: 10.1056/NEJMra0905750, indexed in Pubmed: 20181974.

2. Bartalena L. Graves' orbitopathy: imperfect treatments for a rare disease. Eur Thyroid J. 2013. 2(4): 259-269, doi: $10.1159 / 000356042$, indexed in Pubmed: 24783057.

3. Bartalena L, Baldeschi L, Dickinson A, et al. European Group on Graves' Orbitopathy (EUGOGO). Consensus statement of the European Group on Graves' orbitopathy (EUGOGO) on management of GO. Eur J Endocrinol. 2008; 158(3): 273-285, doi: 10.1530/EJE-07-0666, indexed in Pubmed: 18299459.

4. Melcescu E, Horton WB, Kim D, et al. Graves orbitopathy: update on diagnosis and therapy. South Med J. 2014; 107(1): 34-43, doi: 10.1097/ SMJ.0000000000000038, indexed in Pubmed: 24389785.

5. McAlinden C. An overview of thyroid eye disease. Eye Vis (Lond). 2014; 1: 9, doi: 10.1186/s40662-014-0009-8, indexed in Pubmed: 26605355.

6. Bahn RS. Current Insights into the Pathogenesis of Graves' Ophthalmopathy. Horm Metab Res. 2015; 47(10): 773-778, doi: 10.1055/s-00351555762, indexed in Pubmed: 26361262.

7. Bartalena L, Baldeschi L, Boboridis K, et al. European Group on Graves Orbitopathy (EUGOGO). The 2016 European Thyroid Association/ European Group on Graves' Orbitopathy Guidelines for the Management of Graves' Orbitopathy. Eur Thyroid J. 2016; 5(1): 9-26, doi: $\underline{10.1159 / 000443828}$, indexed in Pubmed: 27099835.

8. Salvi M. Immunotherapy for Graves' ophthalmopathy. Curr Opin Endocrinol Diabetes Obes. 2014; 21(5): 409-414, doi: 10.1097/ MED.0000000000000097, indexed in Pubmed: 25105999.

9. Hegedüs L, Smith TJ, Douglas RS, et al. Targeted biological therapies for Graves' disease and thyroid-associated ophthalmopathy. Focus on B-cell depletion with Rituximab. Clin Endocrinol (Oxf). 2011; 74(1): 1-8, doi: 10.1111/j.1365-2265.2010.03806.x, indexed in Pubmed: 20455896.

10. Salvi M, Vannucchi G, Currò N, et al. Efficacy of B-cell targeted therapy with rituximab in patients with active moderate to severe Graves orbitopathy: a randomized controlled study. J Clin Endocrinol Metab. 2015; 100(2): 422-431, doi: 10.1210/jc.2014-3014, indexed in Pubmed 25494967.

11. Salvi M, Vannucchi G, Currò N, et al. Small dose of rituximab for graves orbitopathy: new insights into the mechanism of action. Arch Ophthalmol. 2012; 130(1): 122-124, doi: 10.1001/archopthalmol.2011.1215, indexed in Pubmed: 22232486 
12. Mourits MP, Prummel MF, Wiersinga WM, et al. Clinical activity score as a guide in the management of patients with Graves' ophthalmopathy. Clin Endocrinol (Oxf). 1997; 47(1): 9-14, indexed in Pubmed: 9302365.

13. Salvi M, Vannucchi G, Campi I, et al. Efficacy of rituximab treatment for thyroid-associated ophthalmopathy as a result of intraorbital B-cell depletion in one patient unresponsive to steroid immunosuppression. Eur J Endocrinol. 2006; 154(4): 511-517, doi: 10.1530/eje.1.02119, indexed in Pubmed: 16556712.

14. Salvi M, Vannucchi G, Campi I, et al. Treatment of Graves' disease and associated ophthalmopathy with the anti-CD20 monoclonal antibody rituximab: an open study. Eur J Endocrinol. 2007; 156(1): 33-40, doi: 10.1530/eje.1.02325, indexed in Pubmed: 17218723.

15. Salvi M, Vannucchi G, Beck-Peccoz P. Potential utility of rituximab for Graves' orbitopathy. J Clin Endocrinol Metab. 2013; 98(11): 4291-4299, doi: 10.1210/jc.2013-1804, indexed in Pubmed: 24009135.

16. Stan MN, Garrity JA, Carranza Leon BG, et al. Randomized controlled trial of rituximab in patients with Graves' orbitopathy. J Clin Endocrinol Metab. 2015; 100(2): 432-441, doi: 10.1210/jc.2014-2572, indexed in Pubmed: 25343233.

17. Bonara P, Vannucchi G, Campi I, et al. Rituximab induces distinct intraorbital and intrathyroidal effects in one patient satisfactorily treated for Graves' ophthalmopathy. Clin Rev Allergy Immunol. 2008; 34(1): 118-123, doi: 10.1007/s12016-007-8024-3, indexed in Pubmed: 18270865.

18. Erdei A, Paragh G, Kovacs P, et al. Rapid response to and long-term effectiveness of anti-CD20 antibody in conventional therapy resistant Graves' orbitopathy: A five-year follow-up study. Autoimmunity. 2014; 47(8): 548-555, doi: 10.3109/08916934.2014.939266, indexed in Pubmed: $\underline{25039242}$.

19. Mitchell AL, Gan EH, Morris M, et al. The effect of B cell depletion therapy on anti-TSH receptor antibodies and clinical outcome in glucocorticoid-refractory Graves' orbitopathy. Clin Endocrinol (Oxf). 2013; 79(3): 437-442, doi: 10.1111/cen.12141, indexed in Pubmed: 23320840.
20. Vannucchi G, Campi I, Covelli D, et al. Effect of a very low dose of rituximab on active moderate-severe Graves' orbitopathy: an interim report. Endocrine Abstracts. 2015, doi: 10.1530/endoabs.37.gp.27.05.

21. Vannucchi G, Campi I, Bonomi M, et al. Rituximab treatment in patients with active Graves' orbitopathy: effects on proinflammatory and humoral immune reactions. Clin Exp Immunol. 2010; 161(3): 436-443, doi: 10.1111/j.1365-2249.2010.04191.x, indexed in Pubmed: 20529087.

22. Miśkiewicz P, Rutkowska B, Jabłońska A, et al. Complete recovery of visual acuity as the main goal of treatment in patients with dysthyroid optic neuropathy. Endokrynol Pol. 2016; 67(2): 166-173, doi: 10.5603/ EP.a2016.0018, indexed in Pubmed: 26884288.

23. Khanna D, Chong KKL, Afifiyan NF, et al. Rituximab treatment of patients with severe, corticosteroid-resistant thyroid-associated ophthalmopathy. Ophthalmology. 2010; 117(1): 133-139.e2, doi: 10.1016/j. ophtha.2009.05.029, indexed in Pubmed: 19818507.

24. Salvi M, Vannucchi G, Campi I, et al. Rituximab treatment in a patient with severe thyroid-associated ophthalmopathy: effects on orbital lymphocytic infiltrates. Clin Immunol. 2009; 131(2): 360-365, doi: 10.1016/j. clim.2008.12.005, indexed in Pubmed: 19195932.

25. Krassas GE, Stafilidou A, Boboridis KG. Failure of rituximab treatment in a case of severe thyroid ophthalmopathy unresponsive to steroids. Clin Endocrinol (Oxf). 2010; 72(6): 853-855, doi: 10.1111/j.13652265.2009.03762.x, indexed in Pubmed: 20039891.

26. Stan MN, Durski JM, Brito JP, et al. Risk factors for development or deterioration of Graves' ophthalmopathy. Thyroid. 2010; 20(7): 777-783, doi: 10.1089/thy.2010.1634, indexed in Pubmed: 20578901.

27. Heemstra KA, Toes RE, Sepers J, et al. Rituximab in relapsing Graves disease, a phase II study. Eur J Endocrinol. 2008; 159(5): 609-615, doi: 10.1530/EJE-08-0084, indexed in Pubmed: 18628345.

28. El Fassi D, Banga JP, Gilbert JA, et al. Treatment of Graves' disease with rituximab specifically reduces the production of thyroid stimulating autoantibodies. Clin Immunol. 2009; 130(3): 252-258, doi: 10.1016/j. clim.2008.09.007, indexed in Pubmed: 18964302. 